\title{
Exposure of honey bees during pesticide application under field conditions
}

\author{
H Koch*, P Weißer \\ Landesanstalt für Pflanzenbau und Pflanzenschutz, Essenheimerstr 144, \\ D-55/28 Mainz, Germany
}

(Received 28 January 1997; accepted 15 October 1997)

\begin{abstract}
Summary - Although pesticides are assessed before registration for whether or not they are harmful to bees there is little information available about the exposure of individual bees during pesticide application under practical conditions. We investigated the exposure of bees in real application situations in flowering apple orchards and Phacelia fields (Phacelia tanacetifolia Benth) in the years 1992-1997. In application trials we used a fluorescent tracer (sodium-fluorescein) at a dose rate of $20 \mathrm{~g}$ per $10000 \mathrm{~m}^{2}$ sprayed area. Bees were collected at the closed hive entrance over a period of 20-30 min in 5-min intervals. The deposit was individually measured on about 100 individual bees per sampling point. Mean initial deposit per trial varied from 1.62 to $20.84 \mathrm{ng} / \mathrm{bee}$ in apple orchards (nine trials) and from 6.34 to $35.77 \mathrm{ng} / \mathrm{bee}$ in Phacelia crops (five trials) with very few highly contaminated individuals. Earlier investigations prove these magnitudes to be realistic. The data give information concerning maximum exposure of individual bees. Results contribute to the discussion of altering concentration-based dose recommendations to product quantities related to the sprayed area.
\end{abstract}

Apis mellifera / pesticides / spraying / exposure

\section{INTRODUCTION}

As long as insecticides are used to control harmful insects in plant protection, beekeepers complain about the effects of chemicals on honey bees (Apis mellifera L). Consequently, legislation and registration implemented testing procedures to assess hazards of pesticides to bees prior to registration. Testing guidelines were developed and label recommendations specified. Since insecticides originally were applied in grapes and fruits by spraying to runoff, dose recommendations have been expressed in terms of concentration without considering the actual quantity applied. Testing procedures

* Correspondence and reprints

Tel: (49) 61319930 16; fax: (49) 6131993080 
of effects on bees also traditionally focused on concentration $(\%)$ rather than on the actual dose (g) applied.

In Germany the BBA-Guideline 23.1 (BBA, 1991) and a directive for the protection of bees exist (Bienenschutzverordnung, 1992), both referring to product concentration in the spray liquid. Although the registration process includes testing of side effects of pesticides on bees, there is almost no information available about real product quantities and the time bees are exposed to the pesticide when fields or orchards are sprayed. Our investigations were aimed at assessing the chemical load of individual bees in field situations in order to understand the dose transfer, which is the process of transforming label recommendations into deposits on targets. This deposit is a measurable chemical quantity and may be used as a base value for estimating effects of chemicals on pests, diseases, and beneficial or other non-target organisms as well. Application of pesticides to fruit crops today is carried out by air-assisted spraying with transportation of small droplets and reduced water volumes in an air stream. Physical characteristics of droplet transportation and deposition on bees in flight or while foraging on flowering crops must be completely different to high volume application and spraying to run off. The investigation does not refer to pesticide quantities collected via pollen or nectar.

\section{MATERIAL AND METHODS}

To organize this type of investigation bee colonies provided by a professional bee keeper were placed next to an appropriate crop, which were two apple orchards and Phacelia fields (Phacelia tanacetifolia Benth). Phacelia is an intensively flowering field crop that is very attractive to bees, and is commonly used as a forage crop for tests on side effects of pesticides on bees (BBA, 1991; EPPO, 1992). At flowering stage bee hives were placed next to the fields 3 days before treatment, to ensure that bees were foraging inside the test plot when starting the test.

Trials were carried out from 1992 to 1997. The number of test runs per season was limited by the short flowering period, especially of apples, and by weather conditions. Nine test runs were conducted in the orchards and five in the Phacelia fields.

The apple orchards were in production and the plot size varied between 0.4 and 1.6 ha. Phacelia was grown in cereal growing areas and the size varied between $0.1(1 \times), 0.2(2 \times)$ and 1 ha $(2 \times)$. As test substance a fluorescent tracer, sodium-fluorescein, was used. It was applied with an axial fan sprayer (Sorarui) and a $12-\mathrm{m}$ boom sprayer (Rau DX 2). Dates and times are presented in tables I and II. The dose rate was

Table I. Technical information on nine trials (apple orchard).

\begin{tabular}{lccccccc}
\hline Trial & Date & $\begin{array}{c}\text { Spraving } \\
\text { time }\end{array}$ & $\begin{array}{c}\text { Sampling } \\
\text { time }\end{array}$ & $\begin{array}{c}\text { Sprayed } \\
\text { area } \\
\text { (ha) }\end{array}$ & $\begin{array}{c}\text { Volume } \\
\text { I/10 000 } \mathrm{m}^{2}\end{array}$ & $\begin{array}{c}\text { Number of } \\
\text { bees/tree }\end{array}$ & $\begin{array}{c}\text { Ground } \\
\text { area } \\
\text { (ha) }\end{array}$ \\
\hline 1 & 28.04 .94 & $08.20-08.45$ & $08.50-09.10$ & 0.434 & 330 & $2-5$ & 0.42 \\
2 & 29.04 .94 & $14.00-14.25$ & $14.30-14.50$ & 0.434 & 330 & $2-5$ & 0.42 \\
3 & 25.04 .95 & $13.25-14.00$ & $14.00-14.20$ & 1.244 & 206 & $1-2$ & 1.085 \\
4 & 02.05 .95 & $13.50-14.28$ & $14.35-14.55$ & 1.244 & 206 & $1-3$ & 1.085 \\
5 & 03.05 .95 & $13.30-14.05$ & $14.00-14.20$ & 1.244 & 206 & 1 & 1.085 \\
6 & 06.05 .96 & $14.25-15.10$ & $14.50-15.15$ & 1.244 & 200 & 1 & 1.085 \\
7 & 07.05 .96 & $10.55-11.38$ & $11.25-11.50$ & 1.244 & 490 & 1 & 1.085 \\
8 & 18.04 .97 & $15.05-15.45$ & $15.25-15.45$ & 1.2 & 217 & 0.5 & 1.2 \\
9 & 25.04 .97 & $15.23-16.17$ & $16.00-16.30$ & 1.64 & 217 & $1.5-2$ & 1.64 \\
\hline
\end{tabular}


Table II. Technical information on five trials (Phacelia).

\begin{tabular}{|c|c|c|c|c|c|c|c|}
\hline Trial & Date & $\begin{array}{c}\text { Spraying } \\
\text { time }\end{array}$ & $\begin{array}{c}\text { Sampling } \\
\text { time }\end{array}$ & $\begin{array}{c}\text { Sprayed } \\
\text { area } \\
\text { (ha) }\end{array}$ & $\begin{array}{c}\text { Volume } \\
1 / 10000 \mathrm{~m}^{2}\end{array}$ & $\begin{array}{c}\text { Number of } \\
\text { bees } / m^{2}\end{array}$ & $\begin{array}{c}\text { Ground } \\
\text { area } \\
\text { (ha) }\end{array}$ \\
\hline 1 & 30.06 .92 & $13.45-14.00$ & $14.00-14.20$ & 1 & 400 & 2 & 1 \\
\hline 2 & 10.09 .92 & 11.20 & $11.25-11.40$ & 1 & 400 & 5 & 1 \\
\hline 3 & 26.05 .93 & 11.00 & $11.05-11.25$ & 0.1 & 400 & $10-12$ & 0.1 \\
\hline 4 & 17.08 .95 & $13.58-14.00$ & $14.05-14.25$ & 0.25 & 400 & $4-5$ & 0.25 \\
\hline 5 & 19.06 .96 & $13.44-13.46$ & $13.50-14.15$ & 0.25 & 400 & $3-5$ & 0.25 \\
\hline
\end{tabular}

$20 \mathrm{~g}$ sodium-fluorescein diluted in $200-500 \mathrm{~L}$ water per $10000 \mathrm{~m}^{2}$ sprayed area. The dose was related to the sprayed area, which is defined, for the apple trees as the calculated size of the fruit wall [different from the ground area (Koch and Weißer, 1995)] or for Phacelia as ground area. Boom spraying in arable crops differs from the application technique used in orchards with a shorter spraying period for the same size of sprayed area.

Immediately before application the number of bees per tree (apples) or per metre squared (Phacelia) was estimated. After spraying, the entrance of the bee hive was closed for about 20-30 min. During this time gathering bees were collected in front of the bee hive at intervals of 5 min, each time put into a box and immediately cooled down in dry ice. Sample size at each sampling point was above 100 bees but could not be kept constant owing to the sampling procedure. After transportation into the laboratory the bees were frozen. For analysis bees were individually rinsed in $10 \mathrm{~mL}$ distilled water. A fluorimeter (Perkin Elmer LS 3B) at $484 \mathrm{~nm}$ excitation and $512 \mathrm{~nm}$ emission wavelength was used to quantify the tracer concentration. Data were transferred on-line into a computer and calculated into nanograms per bee. The described measuring device and procedure can detect the used tracer at concentrations of $0.1 \mathrm{ng} / \mathrm{mL}$ with a traceable limit of $0.05 \mathrm{ng} / \mathrm{mL}$. With $10 \mathrm{~mL}$ of rinsing volume a deposit of $1 \mathrm{ng} / \mathrm{bee}$ can be detected.

In apple orchards, nine test runs were carried out in one orchard per season with two test runs in 1994, 1996 and 1997 and three in 1995. Spraying and sampling were performed at the end of April or the beginning of May, mostly in the early afternoon (table I). Spraying lasted between
25 and $54 \mathrm{~min}$, with a mean of $38 \mathrm{~min}$. A total of 54 samples were taken in the nine trials. We assumed that bees usually return to their hive within about $20 \mathrm{~min}$ (Otten, pers comm). Sampling lasted from 20 to 30 min with a mean of $22 \mathrm{~min}$. Sampling started from $20 \mathrm{~min}$ before the end of spraying to 7 min after spraying, with a mean of $6 \mathrm{~min}$ before the end of spraying.

In Phacelia, five test runs were carried out in one field per season with two test runs in 1992 and one test run in 1993, 1995 and 1996. Spraying and sampling were performed at the end of May to the beginning of September at about noon (table I). No data were available in 1994 owing to scarce nectar flow. Sampling was started immediately after application (table II). Spraying lasted between 1 and $2 \mathrm{~min}$, except in the first trial, where it lasted $15 \mathrm{~min}$. A total of 21 samples were taken in the five trials. Sampling lasted from 15 to $25 \mathrm{~min}$ with a mean of $22 \mathrm{~min}$. Sampling started 0 to $5 \mathrm{~min}$ after spraying (mean: $4 \mathrm{~min}$ ).

\section{RESULTS}

\section{Apple orchards}

In apple orchards the mean deposit per bee was $6.33 \mathrm{ng}$ per returning bee (table III). In eight of the nine trials, mean deposits ranged between 1.62 and $8.51 \mathrm{ng}$ per bee (mean: $4.52 \mathrm{ng}$ per bee). In one trial, mean deposit was exceptionally high (20.84 ng per bee). 
Table III. Apple orchards: frequency distribution with class intervals of $5 \mathrm{ng}$ of individual bees from nine trials. Dose was $20 \mathrm{~g}$ sodium-fluorescein per $10000 \mathrm{~m}^{2}$ sprayed area of fruit wall.

\begin{tabular}{|c|c|c|c|c|c|c|c|c|c|c|c|c|}
\hline \multirow[t]{2}{*}{ Trial } & \multicolumn{10}{|c|}{ Deposit ng/bee } & \multirow{2}{*}{$\begin{array}{c}\text { No of } \\
\text { analysed } \\
\text { bees }\end{array}$} & \multirow{2}{*}{$\begin{array}{l}\text { Mean } \\
\text { deposit } \\
\text { per bee }\end{array}$} \\
\hline & $\begin{array}{l}0 \\
\leq 5\end{array}$ & $\begin{array}{l}>5- \\
\leq 10\end{array}$ & $\begin{array}{l}>10 \\
\leq 15\end{array}$ & $\begin{array}{l}>15 \\
\leq 20\end{array}$ & $\begin{array}{l}>20 \\
\leq 25\end{array}$ & $\begin{array}{l}>25 \\
\leq 30\end{array}$ & $\begin{array}{l}>30 \\
\leq 35\end{array}$ & $\begin{array}{l}>35- \\
\leq 40\end{array}$ & $\begin{array}{l}>40- \\
\leq 45\end{array}$ & $>45$ & & \\
\hline 1 & 81.2 & 13.1 & 1.3 & 2.5 & 0 & 1.0 & 0.5 & 0.4 & 0 & 0 & 239 & 3.81 \\
\hline 2 & 92.6 & 2.9 & 0.8 & 1.3 & 0 & 0.4 & 0.8 & 0.6 & 0 & 0.6 & 227 & 2.21 \\
\hline 3 & 57.2 & 22.9 & 10.1 & 4.8 & 2.2 & 1.0 & 0.6 & 0.4 & 0.8 & 1.6 & 498 & 7.80 \\
\hline 4 & 96.6 & 1.1 & 0.7 & 0.4 & 0 & 0 & 0.3 & 0 & 0 & 1.0 & 480 & 1.62 \\
\hline 5 & 91.2 & 3.6 & 1.4 & 0.6 & 1.0 & 0 & 0.2 & 0 & 0.2 & 1.7 & 490 & 3.39 \\
\hline 6 & 15.7 & 29.5 & 13.2 & 10.7 & 8.5 & 5.7 & 3.0 & 2.8 & 2.2 & 9.0 & 600 & 20.84 \\
\hline 7 & 66.3 & 15.0 & 5.9 & 2.7 & 1.7 & 0.3 & 1.5 & 1.0 & 0.3 & 3.4 & 594 & 8.51 \\
\hline 8 & 86.7 & 9.0 & 0.8 & 1.0 & 0.4 & 0 & 0.2 & 0 & 0 & 1.8 & 488 & 4.44 \\
\hline 9 & 78.36 & 16.4 & 2.7 & 0.4 & 0.1 & 0.3 & 0.3 & 0.3 & 0 & 1.1 & 700 & 4.42 \\
\hline
\end{tabular}

Mean deposit per bee within the 54 individual samples depended on when the time samples were taken. In figure 1 we arranged the mean deposits per sampling point (ng/bee) in relation to application and sampling time as given in table $\mathrm{I}$. Mean deposits of samples increased until the end of application, where they reached $35 \mathrm{ng} / \mathrm{bee}$ in maximum. After spraying had stopped sample mean deposits decreased rapidly and were below $5 \mathrm{ng}$ per bee $10 \mathrm{~min}$ after the end of spraying.

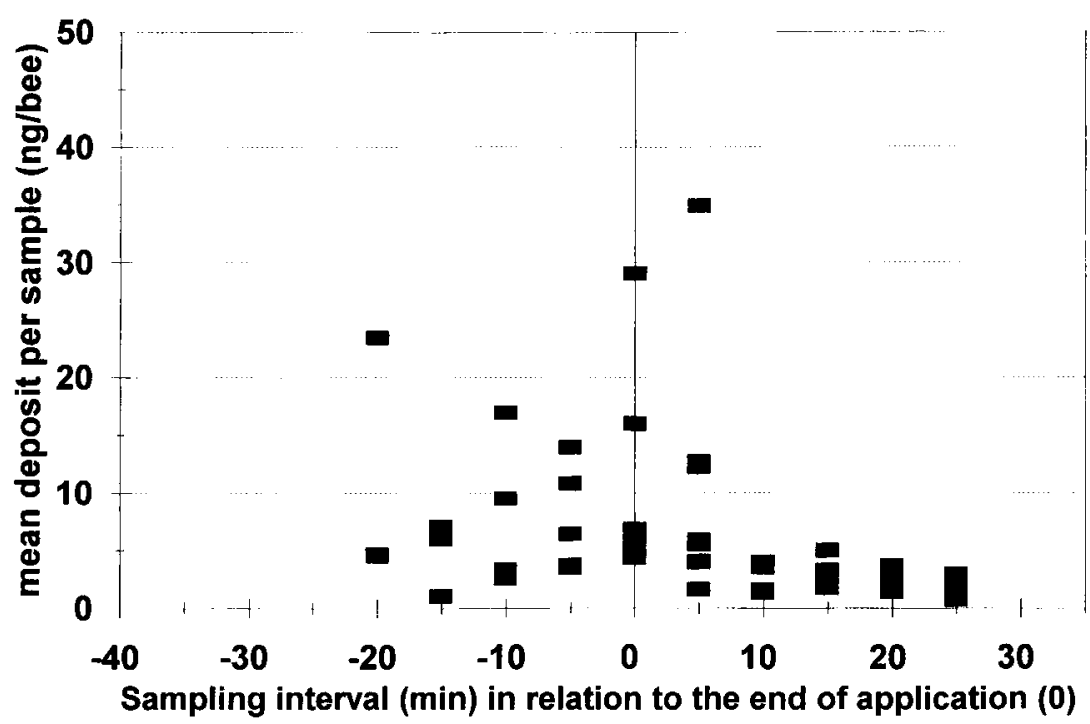

Fig 1. Relation of mean deposit on bees of 54 samples out of nine trials to application and sampling time in apple orchards. Point 0 on the absciss defines the end of application. 
Deposits on individual bees within the trials differed by large amounts. In eight of the nine trials about $75 \%$ of the bees were contaminated with less than $5 \mathrm{ng}$ sodiumfluorescein, about $20 \%$ carried between 5 and $20 \mathrm{ng}$. One trial (No 6) was an exception: $15.7 \%$ of the bees carried less than 5 $\mathrm{ng}$, and $54 \%$ between 5 and $20 \mathrm{ng}$. The mean deposits without trial No 6 was about $4.52 \mathrm{ng}$ per bee (table II). In all trials except trials 1 and 2 we had more than $1 \%$ of bees with more than $45 \mathrm{ng}$ substance per bee, with the maximum proportion of $9 \%$.

\section{Phacelia fields}

In Phacelia fields the mean deposit per bee was $18.19 \mathrm{ng}$ per returning bee (table IV). Mean deposit differed considerably between the five trials and ranged from 6.34 to $35.77 \mathrm{ng}$ per bee.

The mean deposits in the 21 sample points of the five trials in relation to the application time showed the highest values (48 ng) immediately after spraying, with a decrease to below $10 \mathrm{ng}$ after $30 \mathrm{~min}$ (fig 2). In comparison to the apple orchards, this decrease was clearly slower. After $10 \mathrm{~min}$ bees still carried between 8 and $47 \mathrm{ng}$, after $25 \mathrm{~min}$ between 5 and $18 \mathrm{ng}$.

The distribution of deposits on individual bees varied considerably between the trials.
The percentage of bees contaminated with less than $5 \mathrm{ng}$ sodium-fluorescin ranged from 9.0 to $74.5 \%$ (mean about $40 \%$ ), less than $25 \%$ had between 5 and $20 \mathrm{ng}$. The proportion of highly contaminated bees ( $>45 \mathrm{ng}$ per bee) was very high in one trial (34.6\%).

\section{DISCUSSION}

Chemicals may poison bees directly, can cause changes in behaviour (MacKenzie and Winston, 1989; Vandame et al, 1995) or can be transported into bee hives causing effects on the brood (Davis, 1989) or may contaminate the honey (Fernandez Muiño et al, 1995). All these effects depend on the initial deposit per individual bee which totally represents a certain chemical dose. Despite these facts no data are available about direct contamination of individual bees in field situations.

In our investigations we tried to develop a sampling method for accurate assessment of the exposure of individual bees under real life conditions. Although data vary greatly between different trials we can state that the application rate of $20 \mathrm{~g}$ per $10000 \mathrm{~m}^{2}$ sprayed area results in mean deposits of 6.34-35.77 ng/bee in Phacelia and only $1.62-20.84 \mathrm{ng} / \mathrm{bee}$ in apples. In both applications, mean deposits of the samples

Table IV. Phacelia: frequency distribution with class intervals of $5 \mathrm{ng}$ of individual bees from five trials. Dose was $20 \mathrm{~g}$ sodium-fluorescein per ha.

\begin{tabular}{|c|c|c|c|c|c|c|c|c|c|c|c|c|c|}
\hline \multirow[t]{2}{*}{ Trial } & \multirow[t]{2}{*}{ Samples } & \multicolumn{10}{|c|}{ Deposit ng/bee } & \multirow{2}{*}{$\begin{array}{c}\text { No of } \\
\text { analysed } \\
\text { bees }\end{array}$} & \multirow{2}{*}{$\begin{array}{l}\text { Mean } \\
\text { deposit } \\
\text { per bee }\end{array}$} \\
\hline & & $\begin{array}{l}0- \\
\leq 5\end{array}$ & $\begin{array}{l}>5- \\
\leq 10\end{array}$ & $\begin{array}{l}>10 \\
\leq 15\end{array}$ & $\begin{array}{l}>15- \\
\leq 20\end{array}$ & $\begin{array}{l}>20 \\
\leq 25\end{array}$ & $\begin{array}{l}>25- \\
\leq 30\end{array}$ & $\begin{array}{l}>30- \\
\leq 35\end{array}$ & $\begin{array}{l}>35- \\
\leq 40\end{array}$ & $\begin{array}{l}>40- \\
\leq 45\end{array}$ & $>45$ & & \\
\hline & 1 & 60.7 & 12 & 4.7 & 4 & 3.3 & & 0.7 & 1. & & 3. & 150 & \\
\hline 2 & 4 & 12.6 & 8.5 & 8.3 & 10.9 & 12.5 & 14.3 & 8.8 & 9.9 & 4.3 & 10 & 200 & 24.41 \\
\hline & 5 & 74.5 & 8.6 & 4.0 & 4.2 & 2.1 & 2.6 & 2.1 & 0.4 & 1.6 & 0.4 & 360 & 6.34 \\
\hline & 5 & 9.0 & 15.8 & 12.4 & 7.4 & 4.4 & 2.4 & 5.2 & 4.2 & 4.2 & 34.6 & 499 & 35.77 \\
\hline & 6 & 60.4 & 12.5 & 4.0 & 3.2 & 3.4 & 1.5 & 2.1 & 1.8 & 2.2 & 8.8 & 515 & 13.07 \\
\hline
\end{tabular}




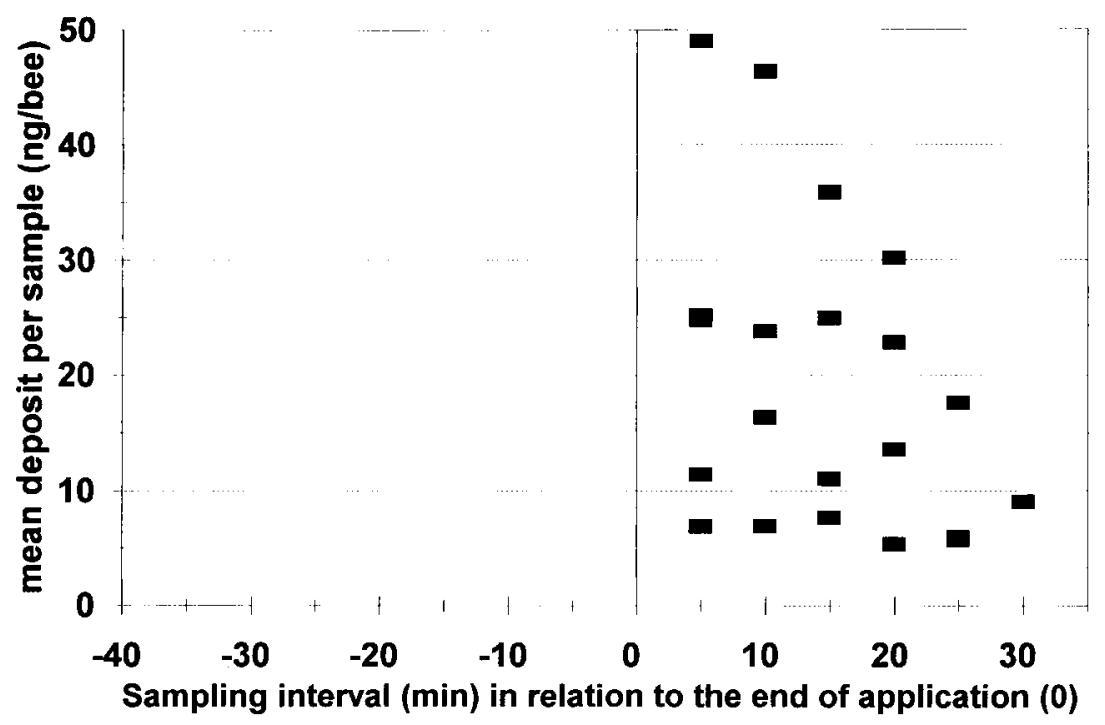

Fig 2. Relation of mean deposit on bees of 21 samples out of five trials to application and sampling time in Phacelia.

decrease within 30 min of the end of spraying at a seemingly slower rate in Phacelia. Mean deposits in the trials reported here should, however, be interpreted with caution, as the sample size was not very large. In some cases individual loads are rather high and one or a few values in the samples were found where individual deposits were above $45 \mathrm{ng} / \mathrm{bee}$.

From the very different application situation compared to orchard spraying and a much higher area spraying capacity (ha/h) mean deposits in Phacelia fields were higher, with in some trials considerable proportions of highly contaminated bees. Although some diffusion of test substance between collected bees in the sampling box could not be avoided because of the 'bulk sampling' technique, a much higher proportion of seemingly uncontaminated bees $(<5 \mathrm{ng})$ was apparent in the apple orchards as compared to the Phacelia fields.

One other major difference between the two investigated spraying methods is the principal difference in spraying duration. To spray apple orchards requires much more time because of the smaller working width in orchard spraying in comparison to a field crop. Thus, the possible exposure period of the colony in orchards is longer. Because of the modified spraying technique in field crops, sprayed acreage is generally much higher and possible exposure time of bees is lower. A $15-\mathrm{m}$ boom field sprayer covers at $6 \mathrm{~km} / \mathrm{h}$ approximately 3 ha in $20 \mathrm{~min}$. Spraying a 3 -ha orchard would require 75 min. Numbers of bees within the samples exposed to spraying thus would differ between these treatments, depending on the difference in area sprayed in the orchards and the Phacelia during the flight time of these bees.

The dose transfer ratio from $20 \mathrm{~g} / 10000 \mathrm{~m}^{2}$ to $35.77 \mathrm{ng} / \mathrm{bee}$ as the highest mean found in our investigations represents a realistic range, as long as water volume is below runoff. No runoff occurred in the trials reported here. The data presented 
here just describe quantitative relations between delivered chemical amount (dose per unit sprayed area) and deposits on bees. The rate of deposits from the individual bees into the colony has not yet been measured. To evaluate possible effects of comparable amounts of pesticides carried by the returning bees into the colonies would have to take into account the distribution of the substance within the colony as well as chemical characteristics and dose effect relations of these substances.

\section{ACKNOWLEDGMENTS}

The authors thank Bayer Pflanzenschutz, Biologische Entwicklung-Versuchswesen, Monheim for supporting the organisation of the trials over the whole period.

\section{Résumé - Exposition des abeilles melli-} fères aux traitements pesticides en conditions de champ. Nous avons étudié l'exposition des abeilles aux traitements phytosanitaires dans des vergers de pommiers et des champs de phacélie (Phacelia tanacetifolia) en fleurs. Bien que le processus d'homologation des produits phytosanitaires inclue des tests de toxicité pour les abeilles établis depuis longtemps, il n'existe jusqu'à présent aucune donnée sur l'exposition réelle des abeilles et sur les quantités susceptibles d'être rapportées à la ruche dans les conditions pratiques de traitement. Les expériences ont été faites avec une substance fluorescente. Les quantités de pesticide appliquées ont été maintenues constantes au cours de l'expérimentation: $20 \mathrm{~g}$ pour $10000 \mathrm{~m}^{2} \mathrm{de}$ surface de feuillage ou pour 1 ha de culture de phacélie. Les colonies ont été installées dans les vergers ou à proximité des champs de phacélie de 1992 à 1997. Immédiatement après le traitement fait par pulvérisateur ou atomiseur, les colonies ont été confinées entre 20 et $30 \mathrm{~min}$ et les abeilles qui rentraient à la ruche ont été prélevées au trou de vol toutes les $5 \mathrm{~min}$. Le trou de vol ne pouvait pas rester fermé plus longtemps car les abeilles devenaient alors trop agressives. Les récipients renfermant les abeilles ont été immédiatement placés dans de la carboglace pour une étude ultérieure au laboratoire. Les abeilles ont été rincées une par une à l'eau distillée et la concentration du traceur a été mesurée par un fluorimètre (Perkin Ellmer LS 3B) à une excitation de $484 \mathrm{~nm}$ et une émission de $512 \mathrm{~nm}$. Au total sept essais ont été faits dans les vergers (tableau I) et cinq dans les champs de phacélie (tableau II). La floraison courte des pommiers n'a permis que deux ou trois séries au maximum de mesures par saison. La taille de l'échantillon était d'environ 100 abeilles par lieu de prélèvement. Cela a permis d'estimer les quantités moyenne et maximale de substance dans chaque échantillon à la fin de chaque essai et de comparer aussi les vergers (culture en volume, atomisation) et la phacélie (cukture en surface, pulvérisation). Les résultats donnent des charges moyennes comprises entre 1,62 et $20,84 \mathrm{~nm} / \mathrm{abeille}$ pour les vergers (tableau III) et entre 6,34 et $35,77 \mathrm{~nm} /$ abeille pour la phacélie (tableau IV).

Une approche dynamique des échantillons montre des différences entre les modes de traitement de la culture en volume et de la culture en surface avec des moyennes plus élevées pour cette dernière (phacélie). Dans les deux cas les charges moyennes diminuent au cours des 30 minutes qui suivent la fin du traitement. D'après d'autres recherches sur les techniques de traitement on peut affirmer que les charges initiales trouvées peuvent être corrélées de façon linéaire avec la dose appliquée. Le doublement de la dose conduit en moyenne, dans les mêmes conditions de traitement, à un doublement de la charge sur les organismes rencontrés, qu'ils soient cibles sou non cibles. On peut ainsi juger les produits avec des doses de traitement très différentes. La seule restriction est que, en raison du mode d'échantillonnage 
(abeilles d'un même prélèvement mises dans un même récipient), une contamination d'une abeille à l'autre n'est pas exclue. Ceci ne joue pas sur la valeur moyenne globale, mais on ne peut éviter que cela influence les valeurs individuelles et la répartition des fréquences. Par ailleurs les résultats montrent une influence de l'attractivité réelle de la culture.

\section{Apis mellifera / exposition / pesticide / pulvérisation}

\section{Zusammenfassung - Exposition von Honigbienen bei Pestizidanwendung unter Freilandbedingungen. In den hier} vorgestellten Untersuchungen wird die Exposition von Bienen bei der Applikation von Pflanzenschutzmitteln in blühenden Apfelanlagen sowie in blühenden PhaceliaBeständen untersucht. Trotz der mit dem Zulassungsverfahren von Pflanzenschutzmitteln seit langem festgeschriebenen Prüfungen der Präparate auf Bienengefährlichkeit gibt es bisher keine Untersuchungen über die tatsächliche Exposition von Bienen und mögliche in den Stock eingetragene Stoffmengen unter praxisüblichen Applikationsbedingungen. Die modellhaften Versuche wurden mit einem fluoreszierenden Farbstoff durchgeführt. Die Stoffaufwandmenge wurde mit $20 \mathrm{~g}$ je $10000 \mathrm{~m}^{2}$ Laubwandfläche bzw. je ha Phacelia-Anbaufläche in den Versuchen konstant gehalten. Bienenvölker wurden in den Jahren 1992 bis 1997 in Apfelanlagen oder neben Phacelia-Bestände gestellt. Unmittelbar im Anschluß an die Applikation mit praxisüblichen Feldspritzgeräten bzw. Gebläsesprühgeräten wurden die Bienenstöcke für etwa 20 bis maximal 30 Minuten verschlossen und die anfliegenden Bienen in Intervallen von 5 Minuten am Flugloch gesammelt. Länger als 20-30 Minuten konnte das Flugloch nicht geschlossen werden, weil sonst die Bienen zu stark irritiert werden. Die Behältnisse mit den Bienen wurden unmittelbar darauf in Trockeneis heruntergekühlt, um die toten Bienen im Labor einzeln untersuchen zu können. Dabei wurde der wasserlösliche Farbstoff von jeder einzelnen Biene abgewaschen und die Konzentration im Fluorometer (Perkin Ellmer LS 3B) bei einer Excitation von $484 \mathrm{~nm}$ und einer Emission von 512 nm gemessen. Insgesamt wurden in Apfelanlagen 7 Versuche gefahren (Tabelle I), in Phacelia lediglich 5 Versuche (Tabelle II). Insbesondere die kurze Blühphase erlaubte beim Apfel nur zwei oder maximal drei Messfahrten pro Saison. Das Stichprobenverfahren umfaßte jeweils ca. 100 Bienen im Abstand von 5 Minuten. Dies erlaubt die Beurteilung der durchschnittlichen sowie maximalen Stoffmengen in den Einzelproben, zu jedem Versuchstermin sowie im Vergleich zwischen Apfel (Raumkultur-Sprühverfahren) und Phacelia (Flächenkultur-Spritzverfahren). Die Ergebnisse zeigen mittlere Belagsmassen in den Versuchen, die im Apfel zwischen 1,62 und 20,84 ng/Biene liegen (Tabelle III). In Phacelia werden Belagsmassen zwischen 6,34 und $35,77 \mathrm{ng} /$ Biene gemessen (Tabelle IV).

Eine dynamische Betrachtung der in Intervallen gesammelten Stichproben zeigt ebenfalls die Unterschiede der Applikationsverfahren in der Feld- und der Raumkultur mit höheren Mittelwerten bei Phacelia. In beiden Fällen nehmen die mittleren Belagsmassen nach Beendigung der Applikation innerhalb von 30 Minuten weitestgehend ab.

Auf Grund anderer applikationstechnischer Untersuchungen kann bestätigt werden, daß die gefundenen Initialbeläge im Verhältnis zur Aufwandmenge linear fortgeschrieben werden können. Verdoppelung der Aufwandmenge führt demnach unter ähnlichen Applikationsbedingungen im Durchschnitt zu doppelten Belagsmassen auf getroffenen Objekten, gleichgültig ob dies Zielobjekte oder Nicht-Zielorganismen sind. Somit ist eine Beurteilung von Präpa- 
raten mit sehr unterschiedlicher Aufwandmenge möglich.

Einzuschränken ist, daß auf Grund des Stichprobenverfahrens, bei dem jeweils die vor dem Stock versammelten Bienen in ein Gefäß gefegt wurden, eine Verschleppung von Biene zu Biene nicht ausgeschlossen ist. Dies beeinflußt nicht den Gesamtmittelwert ggf. jedoch die Einzelwerte und damit die Häufigkeitsverteilung in nicht vermeidbarer Weise.

Andererseits zeigen die Ergebnisse den Einfluß der aktuellen Attraktivität des Pflanzenbestandes. Offen bleibt immer, welcher Anteil der Bienen eines Volkes den untersuchten Bestand anfliegt oder andere Trachten bevorzugt. Während also das Verhältnis von ausgebrachter Aufwandmenge zu angelagerter Stoffmenge in gewisser Größenordnung konstant ist, richtet sich der Anteil getroffener Individuen in erster Linie nach der Attraktivität des Bestandes. Das Applikationsverfahren hat ebenfalls großen Einfluß auf beide Parameter.

\section{Apis mellifera / Pflanzenschutzmittel / Applikation / Exposition}

\section{REFERENCES}

Biologische Bundesanstalt für Land- und Forstwirtschaft (1991) Auswirkungen von Pflanzenschutzmitteln auf die Honigbiene. Richtlinien zur Prüfung von Pflanzenschutzmitteln im Zulassungsverfahren, Teil VI, Nr 23 - 1

Bienenschutzverordnung (1992) Verordnung über die Anwendung bienengefährlicher Pflanzenschutzmittel. BGB1 I, S 1410

Davis AR (1989) The study of insecticide poisoning of honeybee brood. Bee World 70, 163-174

European and Mediterranean Plant Protection Organization (1992) Guideline on test methods for evaluating the side effects of plant protection products on honeybees. EPPO Bull 22, 203-215

Fernández Muiño MA, Sancho MT, Simal Gándara J, Créus Vidal JM, Huidobro JF, Simal Lozano J (1995) Organochloride pesticide residues in Galician (NW Spain) honey. Apidologie 26, 33-38

Koch H, Weißer P (1995) Dose rate and initial deposit - major aspects of pesticide application and efficacy (Aufwandmenge und Initialbelag am Zielobjekt - zwei Kenngrößen für Applikation und Wirksamkeit von Pflanzenschutzmitteln). Nachrichtenbl Dtsch Pflanzenschutzdienstes, 47, 273-278

MacKenzie KE, Winston ML (1989) Effects of sublethal exposure to diazinon on longevity and temporal division of labor in the honey bee (Hymenoptera, Apidae). J Econ Entomol 82, 75 82

Vandame R, Meled M, Colin ME, Belzunces LP (1995) Alteration of the homing, flight in the honey bee Apis mellifera $\mathrm{L}$ exposed to sublethal dose of deltamethrine. Environ Toxicol Chem 14, 855-860 